\title{
Hormone Use in Food Animal Production: Assessing Potential Dietary Exposures and Breast Cancer Risk
}

\author{
Keeve E. Nachman • Tyler J. S. Smith
}

Published online: 8 February 2015

(C) Springer International Publishing AG 2015

\begin{abstract}
In recent years, increasing attention has been paid to the role of hormones in breast cancer etiology, following reports that heightened levels of endogenous hormones and exposure to exogenous hormones and other endocrinedisrupting chemicals through food and the environment are associated with increased breast cancer risk. Seven hormone drugs (testosterone propionate, trenbolone acetate, estradiol, zeranol, progesterone, melengestrol acetate, and bovine somatotropin) are approved by the U.S. Food and Drug Administration for use in food animals. There is concern that these drugs or their biologically active metabolites may accumulate in edible tissues, potentially increasing the risk of exposure for consumers. To date, the potential for human exposure to residues of these compounds in animal products, as well as the risks that may result from this exposure, is poorly understood. In this paper, we discuss the existing scientific evidence examining the toxicological significance of exposure to hormones used in food animal production in relation to breast cancer risk. Through a discussion of U.S. federal regulatory programs and the primary literature, we interpret the state of
\end{abstract}

This article is part of the Topical Collection on Food Health, and the Environment

K. E. Nachman • T. J. S. Smith

Department of Environmental Health Sciences, Johns Hopkins

Bloomberg School of Public Health, Baltimore, MD, USA

K. E. Nachman

Department of Health Policy and Management, Johns Hopkins

Bloomberg School of Public Health, Baltimore, MD, USA

K. E. Nachman • T. J. S. Smith

Johns Hopkins Center for a Livable Future, Johns Hopkins

University, Baltimore, MD, USA

K. E. Nachman $(\bowtie)$

Risk Sciences and Public Policy Institute, Johns Hopkins Bloomberg

School of Public Health, Baltimore, MD, USA

e-mail: knachman@jhu.edu surveillance for residues of hormone drugs in animal products and discuss trends in meat consumption in relation to the potential for hormone exposure. Given the lack of chronic bioassays of oral toxicity of the seven hormone compounds in the public literature and the limitations of existing residue surveillance programs, it is not currently possible to provide a quantitative characterization of risks that result from the use of hormonal drugs in food animal production, complicating our understanding of the role of dietary hormone exposure in the population burden of breast cancer.

Keywords FDA $\cdot$ Hormones $\cdot$ Residues $\cdot$ FSIS $\cdot$ Meat . Milk $\cdot$ Breast cancer

$\begin{array}{ll}\text { Abbreviations } \\ \text { ADI } & \text { Acceptable daily intake } \\ \text { AGD } & \text { Anogenital distance } \\ \text { AR } & \text { Androgen receptor } \\ \text { bST } & \text { Bovine somatotropin } \\ \text { bPR } & \text { Bovine progesterone receptor } \\ \text { CFR } & \text { Code of Federal Regulations } \\ \text { CVM } & \text { FDA Center for Veterinary Medicine } \\ \text { DNFB } & \text { 2,4-ninitro-1-fluorobenzene } \\ \text { DTH } & \text { Delayed-type hypersensitivity } \\ \text { E1 } & \text { Estrone } \\ \text { E2 } & \text { Estradiol } \\ \text { EC } & \text { European Commission } \\ \text { ECa } & \text { Endometrial carcinoma } \\ \text { EDC } & \text { Endocrine disrupting chemical } \\ \text { EFSA } & \text { European Food Safety Authority } \\ \text { EFH } & \text { EPA 2011 Exposure Factors Handbook } \\ \text { EPA } & \text { (United States) Environmental Protection } \\ & \text { Agency } \\ \text { ER } & \text { Estrogen receptor } \\ \text { FAO } & \text { Food and Agriculture Organization of the United } \\ & \text { Nations }\end{array}$




$\begin{array}{ll}\text { FDA } & \text { United States Food and Drug Administration } \\ \text { FOIA } & \text { Freedom of Information Act } \\ \text { FSIS } & \text { Food Safety and Inspection Service } \\ \text { GC } & \text { Gas chromatography } \\ \text { GD } & \text { Gestation day } \\ \text { HPLC } & \text { High-performance liquid chromatography } \\ \text { HRMS } & \text { High-resolution mass spectrometer } \\ \text { HRT } & \text { Hormone replacement therapy } \\ \text { IGF-1 } & \text { Insulin-like growth factor 1 } \\ \text { JECFA } & \text { Joint FAO/WHO Expert Committee on Food } \\ & \text { Additives } \\ \text { LC } & \text { Liquid chromatography } \\ \text { LOD } & \text { Limit of detection } \\ \text { MGA } & \text { Melengestrol acetate } \\ \text { MS } & \text { Mass spectrometry } \\ \text { NADA } & \text { New Animal Drug Application } \\ \text { NCI } & \text { National Cancer Institute } \\ \text { NHANES } & \text { National Health and Nutrition Examination } \\ & \text { Survey } \\ \text { NRC } & \text { National Research Council } \\ \text { NRP } & \text { National Residue Program of the USDA/FSIS } \\ \text { OEHHA } & \text { California Environmental Protection Agency } \\ & \text { Office of Environmental Health Hazard } \\ \text { PND } & \text { Assessment } \\ \text { ppb } & \text { Postnatal day } \\ \text { ppt } & \text { Parts per billion } \\ \text { rBGH } & \text { Parts per trillion } \\ \text { rBST } & \text { Recombinant bovine growth hormone } \\ \text { SC } & \text { Recombinant bovine somatotropin } \\ \text { TBA } & \text { Safe concentration } \\ \text { TB } & \text { Trenbolone acetate } \\ \text { TP } & \text { 17ß-trenbolone } \\ \text { USDA } & \text { Testosterone propionate } \\ \text { WWEIA } & \text { United States Department of Agriculture } \\ & \text { What We Eat In America } \\ & \end{array}$

In the U.S., several active ingredients of drugs approved by the Food and Drug Administration (FDA) for use in food animal production are endogenous hormones (i.e., testosterone propionate [TP], estradiol [E2] and estradiol benzoate, and progesterone) or compounds that display a high affinity for human hormone receptors (i.e., trenbolone acetate [TBA], zeranol, and melengestrol acetate [MGA]) (Table 1) [5]. These drugs are approved for use in cattle and, in the case of zeranol, sheep to increase weight gain and improve feed efficiency (two related indications generally known as "growth promotion"). E2, progesterone, and MGA are also approved to manage estrus in beef cattle and sheep. An additional compound, bovine somatotropin (bST), is approved as a method for increasing milk production in dairy cattle. Hormones are not approved for use in poultry or swine (Table 1).

There is concern that drugs approved for use in cattle and sheep or their biologically active metabolites may accumulate in edible tissues, potentially exposing consumers [6]. There is also concern that bST used in dairy cattle increases levels of another hormone, insulin-like growth factor 1 (IFG-1), in milk and dairy products, likewise increasing consumer exposure [7]. As a result, the use of these drugs has been controversial. The U.S. and European Union (EU) governments have engaged in a decades-long trade dispute over importation of U.S. beef from cattle that have received them [8]. The question of whether these drugs pose a human health risk remains subject to debate $[6,8]$.

The quantitative risk assessment process developed by a National Research Council (NRC) committee in 1983 and updated in 2009 is the standard approach to estimating human health risks posed by exposure to chemicals $[9,10]$. A variant of this process has been adopted by the FDA for evaluation and approval of new animal drugs for use in food animal production [11]. The NAS process consists of four steps: hazard identification, dose-response assessment, exposure

Table 1 FDA drug approvals by species, indication, and status

\section{Introduction}

Breast cancer is a major cause of morbidity and mortality in the United States. The National Cancer Institute (NCI) estimated that 232,340 women would be diagnosed with breast cancer in 2013 and 39,620 women would die of it [1]. The $\mathrm{NCI}$ also estimated that the lifetime breast cancer risk of women born today is 1 in 8 . Given the public health burden, extensive research on risk factors is currently underway. In recent years, increasing attention has been paid to the role of hormones in breast cancer etiology, following reports that heightened levels of endogenous hormones and exposure to exogenous hormones and other endocrine-disrupting chemicals through food and the environment are associated with increased breast cancer risk $[2 \bullet, 3,4]$.

\begin{tabular}{|c|c|c|c|c|c|c|c|c|}
\hline $\begin{array}{l}\text { Active } \\
\text { ingredient }\end{array}$ & Beef & Dairy & Sheep & WG & FE & Estrus & Milk & Status \\
\hline $\begin{array}{l}\text { Estradiol } \\
\text { benzoate }\end{array}$ & $\mathrm{x}$ & & & $\mathrm{x}$ & $\mathrm{x}$ & $\mathrm{x}$ & & OTC \\
\hline $\begin{array}{l}\text { Melengestrol } \\
\text { acetate }\end{array}$ & $\mathrm{x}$ & & & $\mathrm{x}$ & $\mathrm{x}$ & $\mathrm{x}$ & & OTC \\
\hline Progesterone & $\mathrm{x}$ & & $\mathrm{x}$ & $\mathrm{x}$ & $\mathrm{x}$ & $\mathrm{x}$ & & OTC \\
\hline BST & & $\mathrm{x}$ & & & & & $\mathrm{x}$ & OTC \\
\hline $\begin{array}{l}\text { Testosterone } \\
\text { propionate }\end{array}$ & $\mathrm{x}$ & & & $\mathrm{x}$ & $\mathrm{x}$ & & & OTC \\
\hline $\begin{array}{l}\text { Trenbolone } \\
\text { acetate }\end{array}$ & $\mathrm{x}$ & & & $\mathrm{x}$ & $\mathrm{x}$ & & & OTC \\
\hline Zeranol & $\mathrm{x}$ & & $\mathrm{x}$ & $\mathrm{x}$ & $x$ & & & OTC \\
\hline
\end{tabular}

$W G$ weight gain, $F E$ feed efficiency, Estrus egulation/modification of estrus, Milk increased milk production, OTC over the counter, BST bovine somatotropin 
assessment, and risk characterization [9]. This report summarizes the information available to inform each of these steps with respect to the seven drugs described above (IGF-1 is assessed as the exposure of concern linked to bST), and identifies research gaps that need to be filled in order to more adequately elucidate any risk of breast cancer or other adverse outcomes posed by their use.

\section{Toxicologic Evaluation}

The hazard identification and dose-response steps of the risk paradigm for the seven hormone drugs are combined and summarized in this section, encompassing details from published in vitro, in vivo, and epidemiologic studies. The studies are grouped by hormone, and the hormones are grouped by their primary hormone receptor (androgen, estrogen, progesterone, and IGF-1). We have limited the scope of our review to studies in mammalian species, and given the state of the literature, a formal dose-response assessment was not pursued.

\section{Androgen Receptor}

\section{Testosterone Propionate}

In cattle, testosterone propionate (TP) is rapidly metabolized to a form that is indistinguishable from endogenous testosterone [12]. Testosterone metabolism in cattle is not well characterized [12]. Prospective epidemiologic studies have found an association between circulating levels of testosterone and increased breast cancer risk in postmenopausal women [13-15]. Conversely, an inverse relationship between circulating levels of the testosterone precursor dehydroepiandrosterone and risk of breast cancer has been reported in premenopausal women [16] It is believed that androgens antagonize estrogen-dependent cell growth in premenopausal women via one mechanism but stimulate cell growth in postmenopausal women via a different mechanism [16]. (For reviews of the role of androgens in breast and other cancers, see $[17,18]$.)

In animals, testosterone has been associated with a number of adverse reproductive and developmental effects. In female rats exposed to $1 \mathrm{mg} \mathrm{TP}$ in utero on gestation days (GDs) 16 or 19 , and then to $1 \mu \mathrm{g}$ TP on postnatal days (PNDs) 1 or 5, a high percentage of animals within groups exposed on GD 19 had modified vaginas and sexual behavior deficits compared to both vehicle-only controls and groups exposed on GD 16 [19]. This 1983 report supports the importance of "windows of toxicity," in which effects are dependent upon the developmental stage of the receptor organism. In a different study, masculinized external genitalia was more common in female rats born of dams injected with $2 \mathrm{mg}$ /day TP on GDs 16-20 than in female rats born of vehicle-only controls, although postnatal ovarian cyclicity was normal [20]. In a third study, pregnant rats were injected with $0.5,1,2,5$, or $10 \mathrm{mg} /$ day TP on GDs 14-19. The authors reported several "androgenic effects" in rat offspring at $0.5 \mathrm{mg} /$ day $\mathrm{TP}$, including increased anogenital distance (AGD) at weaning and in adulthood, as well as reduced numbers of nipples and areolas [21]. In a fourth study, the same group reported that rats born of dams injected subcutaneously with 1.5 or $2 \mathrm{mg} /$ day TP on GDs 14-18 had increased AGD at PND 2 (AGD remained slightly but non-significantly increased at PND 13), reduced numbers of nipples and areola, and several genital malformations [22].

\section{Trenbolone Acetate}

In cattle, trenbolone acetate (TBA) is metabolized to its most active form, $17 \beta$-trenbolone (TB), and then further metabolized to $17 \alpha$-trenbolone, which is also biologically active, and trendione, which is not biologically active [23]. As the most active form of TBA, TB is the predominant focus of the toxicologic literature. In contrast to assessments of its endocrine effects, genotoxicity assays of TB have produced mostly negative results [12], although a number of these tests were conducted by the industry [24], and some positive experiments have been reported as well $[25,26]$. TB has induced neoplastic transformations in Syrian hamster embryo cells in vitro in multiple experiments $[25,27,28]$.

In general, the in vivo literature is sparse, and no published study of carcinogenicity was identified. Instead, studies have examined reproductive and developmental endpoints. In the castrated rat, TB increased the combined weight of androgensensitive reproductive tissue and decreased body and adrenal gland weights relative to controls immediately following subcutaneous injections of $50 \mu \mathrm{g} /$ day for 10 days (days 56-65) [29]. In a $200-\mu \mathrm{g} /$ day group, those effects were elevated further. In another study reported simultaneously, TB administration by gavage, also on days 56-65, increased androgensensitive tissue weight relative to controls beginning at $10 \mathrm{mg} / \mathrm{kgBW} /$ day [29]. At $50 \mathrm{mg} / \mathrm{kgBW} /$ day, these effects were heightened, and other, similar effects were also observed.

In a two-generation rat study, the same group reported that subcutaneous TB injections during pregnancy $(0,0.1,0.5,1$, or $2 \mathrm{mg} /$ day for 6 days, on gestation days 14-19) caused few effects in dams (only body weight was measured, and while a decrease was reported, statistical significance varied with the test utilized) [29]. At PND 2, however, AGD increased in a dose-dependent manner in $F_{1}$ female pups from $0.5 \mathrm{mg}$ /day. At PND 13, the total number of nipples displayed was reduced in $\mathrm{F}_{1}$ females at $2 \mathrm{mg} /$ day, but the number of normal nipples displayed was reduced at $0.5 \mathrm{mg} /$ day. In a continuation of the same study, AGD remained elevated at PND 23 in the 2-mg/ 
day group, with dose-dependent increase in AGD at 0.5 and $1 \mathrm{mg} /$ day, albeit non-significantly [30]. The total number of nipples displayed at PND 23 likewise remained significantly reduced at $2 \mathrm{mg} /$ day; some nipples were still missing in the 1$\mathrm{mg}$ /day group, but this was also not significant. TB delayed vaginal opening (i.e., the onset of puberty) at $2 \mathrm{mg}$ /day and induced a number of genital malformations at various doses, beginning at $0.5 \mathrm{mg} /$ day. In $\mathrm{F}_{2}$ pups, survival was reduced at PNDs 1 and 6 at $1 \mathrm{mg} /$ day.

In a separate study, castrated mice were injected subcutaneously with TB each day for two weeks, and then sensitized to a T-cell antigen, 2,4-ninitro-1-fluorobenzene (DNFB) [31]. At one week following sensitization, DNFB was applied to the right pinna of each mouse. The mice were monitored for delayed-type hypersensitivity (DTH) as indicated by pinna thickness, measured daily for one week. TB reduced DTH in a dose-dependent manner at both doses (50 and $200 \mu \mathrm{g} /$ day). The responsible mechanism was unknown, although endogenous androgens are involved in immunosuppression [32, 33]. In addition, weights of androgen-sensitive reproductive tissues were decreased at both doses, in contrast to increased weights observed in castrated rats. No attempt was made to explain the contradictory result.

The FDA's website includes two Freedom of Information Act (FOIA) summaries, from 1986 and 1996 [34, 35]. In 1986, increased incidence of "hepatic neoplasia and hyperplasia" relative to controls was reported in male and female rats that received TBA in their diet at 100 parts per million (ppm) for 96 weeks (males) or 104 weeks (females). From another study, an FDA committee concluded that "increased incidence of pancreatic islet cell tumors" observed in rats born of dams that received TBA in the diet was not "a carcinogenic effect of trenbolone acetate," but no further detail or explanation was provided. In 1996, carcinogenicity was not reported, but "mammary gland atrophy was more frequent and/or severe" in female rats that received TBA at $16 \mathrm{ppm}$ in their diet for 12 months than in controls. From the 1986 approval, the FDA determined that "hormonal activity" was the critical effect of TBA and, from a study in the female rhesus monkey, identified $40 \mu \mathrm{g} / \mathrm{kgBW} /$ day as the hormonal noeffect level [34]. The ADI established by the FDA is $0.4 \mu \mathrm{g} /$ $\mathrm{kgBW} /$ day [36], presumably due to the division of the specified no-effect level by safety factors totaling 100 , although the factors applied by the FDA are not presented in the summary.

\section{Estrogen Receptor}

\section{Estradiol}

In cattle, estrogen benzoate is converted to estradiol (E2) [37]. E2 is more potent than two other physiologic estrogens, estrone (E1) and estriol [38]. Following the administration of radiolabeled $\mathrm{E} 2$ to cattle, the predominant metabolite detected in urine was $17 \alpha$-estradiol, as well as E1 and conjugates of E1 and E2 [37]. There is clear evidence that estrogen is a mammary carcinogen, in part based on results from large epidemiologic investigations of its safety for hormone replacement therapy in menopause [2•]. It is believed that estrogen can act as both an initiator and promoter in breast carcinogenesis. Its action as an initiator is effected by E2 metabolites that can bind and damage DNA directly and by other metabolites that can elicit DNA damage via oxidative stress. As a promoter, E2 binds estrogen receptors (ERs) and elicits both cell proliferation and inhibition of apoptosis.

Because the carcinogenicity of estrogen is better supported by current evidence, and is reviewed in detail elsewhere [2•], we have limited our review of the literature in this report.

\section{Zeranol}

In cattle, zeranol is metabolized to several compounds ( $\alpha$ - and $\beta$-zearalenol and $\alpha$ - and $\beta$-zearalanol), although the literature has focused primarily on the parent compound. Zeranol is an ER agonist with potency similar to diethylstilbestrol and estradiol-17 $\beta$ (see above) [39]. In vitro studies provide the clearest evidence that zeranol is a mammary carcinogen. Repeated zeranol treatments were shown to reduce cell doubling time, stimulate colony formation, and, most notably, induce expression of ER- $\beta$ mRNA in the MCF-10A human breast epithelial cell line [40]. Because MCF-10A is putatively ER-negative, the authors suggest that induction of ER- $\beta$ mRNA may have been redox-mediated (e.g., genotoxic; see "Estradiol" above). In ER-positive human breast carcinoma cells, low concentrations of zeranol were found to accelerate cell growth, but the same concentrations did not affect the growth of ER-negative cells [41]. At a higher concentration, zeranol induced apoptosis of both ER-positive and ER-negative cells. This report is consistent with an emerging scientific consensus on the importance of low-dose effects distinct from overt cytotoxicity at higher doses [3]. Another study found that zeranol increased the proliferation of cancerous human breast epithelial cells to a greater degree than normal cells and down-regulated expression of the tumor suppressor gene p53 [42]. Ex vivo studies of cells isolated from the tissues of rats and beef heifers implanted with zeranol have found that further exposure to zeranol in vitro increases cell proliferation, upregulates oncogenes (e.g., cyclin D1), and/or downregulates tumor suppressor genes (e.g., p53) relative to cells from tissues of untreated animals [43, 44].

Evidence from in vivo studies is more equivocal, and studies to date have been hampered by small sample size, short duration, and the limited attention paid to carcinogenicity. Sheffield and Welsch [45] found that ovariectomized mice (5-8 mice per group) injected 
subcutaneously with zeranol from weeks 6 to 8 , and then sacrificed immediately, displayed increased mammary gland growth relative to controls [45]. In contrast, two studies, one in mice ( 30 per group) and the other in rats (24 per group), found no significant effect on mammary gland growth or carcinogenesis following prepubertal (days 15-18) exposure to zeranol by subcutaneous injection [46, 47]. In the rat study, animals were injected with the carcinogen $\mathrm{N}$-methyl-N-nitrosourea at 10 days following the last zeranol injection (day 28). Zeranol did not significantly affect mammary carcinogenesis by week 37. In contrast, zeranol exposure has been associated with precancerous changes in the liver of the Armenian hamster [48], which is especially sensitive to estrogen, and in the prostate of the Akkaraman lamb [49].

\section{Progesterone Receptor}

\section{Progesterone}

In humans, progesterone has a number of clinical applications; it is often administered in combination with estrogen during hormonal therapy [50], and has been shown to aid in the effectiveness of chemotherapy drugs (such as cisplatin) [51]. Progesterone therapy has been suggested to reduce the risk of spontaneous preterm delivery [52], and has been proposed as having neuroprotective effects when administered with estrogen [53]. Much of the epidemiologic evidence available for progesterone relates to its use in hormone replacement therapy (HRT). It has been shown that HRT increases the risk of breast cancer in postmenopausal women [54]. In a study of the specific modalities of HRT in an investigation conducted in the UK with a sample size exceeding 1 million women, it was observed that HRT with an estrogen-progesterone combination was responsible for an increase in breast cancer risk over and above that associated with estrogen treatment alone [55]. Other studies have shown that the addition of progestins to HRT can reduce the risk of endometrial cancer [56]. With regard to breast cancer, one prospective study of plasma levels of endogenous steroid hormones did not find a significant association between progesterone levels and breast cancer in postmenopausal women, despite seeing evidence of a relationship for estrogens (E1 and E2) and testosterone [15]. Other studies have examined breast cancer risk in premenopausal women; in one large study, a significant inverse association between progesterone levels and breast cancer risk was observed, whereas four smaller studies and a second large study did not find significant associations [57].

A study in postmenopausal mice has shown that hormonal therapy with estrogen and progesterone stimulates epithelial cell proliferation, which is believed to be a factor in the development of breast cancer [58].
Aside from its potential role in breast carcinogenesis, progesterone has been shown to have other cellular effects. Studies in rats have demonstrated that progesterone treatment can increase cellular susceptibility to the effects of cadmium [59, 60]. A different study in the ovaries of Chinese hamsters and four different human cell lines (HeLa, Chang liver, Hep G2, and $\mathrm{Caco}-2$ ) found that progesterone treatment inhibited cholesterol synthesis, resulting in the accumulation of cholesterol precursors, ultimately resulting in cholesterol auxotrophy [61].

\section{Melengestrol Acetate}

MGA metabolism in cattle remains unclear: according to one study reported by employees of an MGA sponsor, the percentage of total residue accounted for by MGA was $29 \%$ in the liver and kidney, $48 \%$ in muscle, and $84 \%$ in fat [62]. A number of metabolites were detected but not identified. MGA and other progestins have been investigated in animals as chemoprophylactic agents against hormone-sensitive cancers, including breast cancer. In the rat, $5 \mu \mathrm{g} \mathrm{MGA} / \mathrm{g}$ feed for 30 days was associated with increased mammary lobulo-alveolar development relative to controls in intact animals but not ovariectomized animals [63]. In SHN virgin mice $(n=25), 10 \mathrm{mg}$ MGA implanted subcutaneously increased mammary tumorigenesis but slightly inhibited the formation of preneoplastic hyperplastic alveolar nodules relative to controls $(n=44)$ implanted with cholesterol [64]. The authors suggested that heterogeneity in the hormonal response of clones accounted for these seemingly contradictory responses. In the BDII/Han rat, in which incidence of endometrial carcinoma (ECa) approaches $90 \%$ in later life, MGA suppressed ECa in all rats receiving 250,500 , or $1,000 \mathrm{ppm}$ MGA in their diet from days 24 to $28(n /$ group $=17-20)$, while the incidence in untreated controls $(n=20)$ was $85 \%$ [65].

In addition to controlled experiments in rodents, mammary carcinogenicity has been reported in small observational studies of captive wild felids in which MGA was used as a contraceptive [66] (others are cited in [67]). There is also evidence that prepubertal exposure to MGA accelerates the onset of puberty in the beef heifer [68]. Reproductive toxicity per se was not assessed in the published literature; in the rabbit, however, oral administration of MGA to two dams on gestation day (GD) 14 increased MGA residues in fetal tissues at GD 27, indicating in utero exposure [69].

\section{Insulin-Like Growth Factor 1 Receptor}

Insulin-like growth factor 1 (IGF-1) is an endogenous protein hormone produced by the liver in response to somatotropin [70]. Bovine somatotropin (bST or, in some cases, bovine growth hormone $[\mathrm{bGH}]$, recombinant bovine 
somatotropin [rbST], and recombinant bovine growth hormone $[\mathrm{rbGH}]$ ) is approved by the FDA for use in dairy cattle to increase milk production [5]. It is injected subcutaneously. As acknowledged by the FDA and the industry, the use of bST increases IGF-1 levels in milk, although the magnitude of this increase has been disputed [71-73] (see the following section). The key questions for a toxicological evaluation in support of risk assessment include what fraction of IGF-1 in milk is absorbed intact in the human gut, how this affects endogenous IGF-1 in circulation, and the biological significance of an increase in circulating IGF-1 levels.

Bovine IGF-1 in milk is identical to human IGF-1 [71]. Nevertheless, the FDA and industry maintain that milkborne IGF-1, as a protein hormone, is digested in the gut and not absorbed intact $[71,73]$. For that reason, IGF-1 was approved with limited toxicity studies (two 2-week experiments in the rat). Both assays included groups dosed subcutaneously and groups dosed by gavage [71, 72]. Treatmentrelated effects were observed only in the subcutaneous groups, and it was argued that this supports the contention that IGF-1 is not orally active. It could not be determined from published reports whether a change in circulating IGF1 levels was assessed in either study. The effect of lifetime oral exposure, which is more relevant when the vehicle is milk, was not assessed. The latency periods of clinical endpoints associated with increased circulating IGF-1 levels in the epidemiologic literature (e.g., breast, colorectal, and prostate cancers) is almost certainly longer than two weeks in the rat.

The relationship between plasma and serum IGF-1 levels and breast cancer risk has been assessed in numerous epidemiologic studies. A 2004 meta-analysis of six case-control studies reported significant associations in premenopausal women (OR [95 \% CI] $=1.65$ [1.26-2.08]) but not in postmenopausal women (0.95 [0.65-1.58]) [74•]. However, a more recent meta-analysis of individual data from 17 prospective studies reported associations in both premenopausal and postmenopausal women (ORs [95\% CIs] $=1.21[1-1.45]$ and 1.33 [1.14-1.55], respectively) [75•]. Heightened IGF-1 levels have also been associated with increased risk of colorectal and prostate cancers [74•]. The reported associations between circulating IGF-1 levels and cancer risks are supported by biologically plausible mechanisms [76].

Dairy consumption has been associated with higher circulating IGF-1 levels [77, 78]. Despite this fact, a weak association between dairy consumption and breast cancer risk was found in one meta-analysis [79], and no significant association was found in another [80]. Dairy consumption may not be an appropriate surrogate for IGF-1 exposure attributable to bST use, however, as IGF-1 and other hormones are present in the milk of untreated cows, and by 2008 , the use of bST had fallen to $17.2 \%$ of the U.S. dairy herd $[81,82]$.

\section{Residues of Hormones and Hormone Metabolites in Food Animal Products}

Understanding the burden posed by dietary hormone exposure requires data on residue levels in food animal products. For hormones administered to food animals, in order to obtain FDA approval, drug companies (known as "sponsors") are required to conduct feeding studies that show the rates of depletion of these compounds in the edible tissues of dosed food animals. These studies are used to inform recommended dosages and to set withdrawal periods (i.e., the number of days before slaughter that use of the drug must end) that are intended to ensure that remaining residue concentrations have fallen to levels the FDA considers "safe" for human consumption. In addition, some residue data are available from federal food safety monitoring programs and independent research studies. Available data are described below.

\section{Residue Determination Via Food Animal Feeding Studies} and Retail Market Samples

As part of the NADA process, the sponsor of a new animal drug is required to conduct and submit studies to the FDA that characterize residues that may persist in animal products when the drug is used in accordance with the conditions of use proposed in the NADA. The extent of study data and summaries that are publicly accessible is limited. Even for drugs where residue depletion summaries are accessible, confidence in any of the conclusions drawn is limited by problems with data design and results reporting. An example can be found in the case of NADA 141-043, for a combination implant drug containing TBA and estradiol benzoate [83]. In the FOIA summary associated with this approval, serious issues are apparent regarding study design (i.e., data from half [heifers] of the 24 animals tested were dropped, leaving only 12 animals [steers], with unspecified exposure group assignment) and reporting clarity (i.e., number of animals per group is not reported, no control data are reported, urinary and fecal residue measurements are not reported) that would challenge the value of this study for determining anticipated residues. In this particular case, the study was used to support the decisions not to require marker residue tolerance or withdrawal periods for the drug.

Feeding studies conducted outside the NADA process were uncommon. Daxenberger and colleagues examined residues of MGA that persisted in edible tissues and plasma under FDA-approved conditions of use and following overdosage (i.e., 3-10 times the approved dose) in heifers post-56-day treatment [84]. Detectable residues of MGA were observed in tissues in the following order: fat $>>$ liver $>$ kidney $>$ muscle $>$ plasma, with increasing residue concentrations tracking with increases of administered dose. The authors found that tripling the recommended dose resulted in fat residue 
concentrations that exceeded FDA residue tolerance levels. A compilation of studies of experimental animals implanted with hormones (written in French and summarized by the European Food Safety Authority [EFSA]) examined tissues for residues of endogenous and exogenous hormones in treated and control animals [85]. For the examined exogenous hormones (zeranol and trenbolone), measurable concentrations (from sub-parts-per-billion [ppb] to single-digit ppb concentrations) were present in all tissues examined (liver $>$ kidney $>$ muscle $\sim$ fat). Marked increases were seen in endogenous hormone (E2, testosterone, and progesterone) residues of implanted animal tissues, with greater differences seen in nonliver tissues (with the exception of E2).

While the literature describing various techniques for determining hormone residues in animal products is expansive, few studies were identified of residues in retail animal products, and mid- or large-scale evaluations of residues in retail animal products were not identified. The focus of the majority of studies identified was on free/unconjugated hormone residues, as these are believed to be the most biologically active forms [86]. Concerns have been raised, however, that conjugated estrogens can be deconjugated in the gastrointestinal tract, resulting in the release of free forms of these compounds, which then may become available for absorption and subsequent binding to hormone receptors [87].

To date, the largest body of literature available is for hormone residues in dairy products; studies of E1 and E2 levels in various milk products were most common. Studies typically analyzed small numbers of retail samples; single samples per product type were not uncommon, and studies rarely exceeded ten samples per product. Estrogens, particularly forms of E2, were the most frequently examined [86, 88-92]. Looking across studies, some patterns emerge, though it is necessary to acknowledge that the limited number of studies and small sample sizes within those studies do not allow for statements of great certainty.

Free E2 (non-specific to $\alpha$-E2 and $\beta$-E2 forms) concentrations in milk samples have been reported in ranging from less than the limit of detection (LOD) to $5.84 \mathrm{pg} / \mathrm{mL}[86,90,92]$. Studies of free $\alpha$-E2 and $\beta$-E2 in milk found concentration levels ranging from below the LOD to $3.7 \mathrm{pg} / \mathrm{mL}$ and 0.5 $10.7 \mathrm{pg} / \mathrm{mL}$, respectively. Generally, as the fat content of milk increased, free E2 concentrations were higher (this was observed especially in $\beta$-E2, less so in $\alpha$-E2) [92]. No differences in E2 concentrations were observed when comparing USDA certified organic milk to conventionally produced milk [90], though comparisons of unprocessed (raw) milk and processed milk showed that the processing step can significantly reduce free E2 concentrations [91]. Reported ranges of total (free and deconjugated) E2 spanned 20.4 to $61.52 \mathrm{pg} /$ $\mathrm{mL}$, with the highest concentrations found in samples with the most fat content $[86,90]$. Total levels of $\alpha$-E2 and $\beta$-E2 did not appear to track well with fat content $[88,91]$. A single study examined raw milk across the three trimesters of pregnancy, and found a clear trend in E2 levels increasing with trimester [91]. One study reported total E2 concentrations in butter, cream, and half-and-half of 15.8 and $6 \mathrm{pg} / \mathrm{g}$, and $1.9 \mathrm{pg} /$ $\mathrm{mL}$, respectively [92].

A limited number of studies examined E1 levels in dairy products. Among processed milk samples, free E1 concentrations ranged from 1.1 to $14.45 \mathrm{pg} / \mathrm{mL}$ [86-88, 90, 92]. A single study reported a free E1 concentration of $28.3 \mathrm{pg} / \mathrm{g}$ in milk fat. Some variability was observed across studies in free E1 concentrations within the same types of dairy products (a single study reported considerably lower concentrations than all others). In the aforementioned study looking at raw milk across trimester or pregnancy, E1 concentrations were highest in late pregnancy, and the impact of milk processing was significant on residual free E1 [91]. Studies of total E1 reported levels ranging from 8.2 to $397.0 \mathrm{pg} / \mathrm{mL}$ in processed milk, and a peak value of $1,266 \mathrm{pg} / \mathrm{mL}$ in raw milk from a cow in its third trimester of pregnancy [87-91]. One study examined butter, cream, and half-and-half, reporting total E1 concentrations of $118.9 \mathrm{pg} / \mathrm{g}, 54.1 \mathrm{pg} / \mathrm{g}$, and $20.4 \mathrm{pg} / \mathrm{mL}$, respectively [92].

Two French studies by the same group examined levels of testosterone in dairy products $[88,89]$. The first, which measured $\alpha$-testosterone, reported a concentration range of 27.46 to $94.86 \mathrm{ng} / \mathrm{L}$ [89]. Concentrations increased as a function of fat content of the milk. The other study reported a range for total testosterone of 2.9-20.4 ng/L [88] (more than 50\% of which was in conjugated form), which was considerably lower than the group's earlier study. No obvious patterns were observed for total testosterone with regard to fat content. The same two French studies examined residues of total $\alpha$ $\mathrm{E} 2$ and $\beta$-E2, E1, and $\alpha$-testosterone and $\beta$-testosterone in eggs [88], finding measurable levels of all compounds. Concentrations ranges of $0.03-0.85$ and $0.15-1.45 \mu \mathrm{g} / \mathrm{kg}$ were reported for $\alpha$-E2 and $\beta$-E2, whereas E1 was measured at $0.15-2.47 \mu \mathrm{g} / \mathrm{kg}$. The earlier of the two studies measured levels of $1.54-2.62$ and $1.06-1.56 \mu \mathrm{g} / \mathrm{kg}$ for $\alpha$-testosterone and $\beta$-testosterone, respectively, and the later study found a range of $0.16-1.88 \mu \mathrm{g} / \mathrm{kg}$ for total testosterone.

Concerns related to the use of rBST have focused on resulting levels of IGF-1 in milk products. While IGF-1 is present in untreated cow's milk, the use of rBST has been examined for its propensity to increase concentrations of the drug in commercial milk [93]. The European Commission (EC) published a report in 1999 that examined available literature regarding impacts of rBST treatment on IGF-1 levels [94]. The report found evidence that rBST treatment resulted in milk IGF-1 concentrations two to five times greater than those in milk from untreated animals. Earlier research cited in the EC report had identified a range of IGF-1 concentrations in cow's milk of 1-34 ng/mL, whereas later research found that milk from treated animals had an average concentration of 
$5.9 \mathrm{ng} / \mathrm{mL}$ as compared to an average of $3.7 \mathrm{ng} / \mathrm{mL}$ in untreated animals (the difference was statistically significant) [95]. JECFA reported concentrations of IGF-1 in milk from treated and untreated cows in a range of $1-13$ and $1-9 \mathrm{ng} / \mathrm{mL}$, respectively, and noted that the levels of IGF-1 were influenced by stage of lactation, nutritional status, and animal age. Attempts to find additional studies of IGF-1 levels in commercial milk were unsuccessful, though references in the literature of declining frequency of rBST use were found [81].

A smaller number of studies have attempted to characterize residues of synthetic hormones in beef products [88, 96-98]. One study successfully measured hormone residues in these products, finding fractions of ppb residues in the liver, kidney, and muscle tissue of cattle implanted with E2 and TBA [88]. Most other studies examined beef tissue for residues of zeranol, and never found concentrations above quantitation limits $[96,97]$. One older study that lacked a clear description of its analytical methods looked at beef liver, kidney, and muscle tissue for a suite of hormones (E2, MGA, progesterone, TBA, testosterone, and zeranol) and found no measurable residues [98]. A Turkish study of meat and sausage products from markets in Istanbul [99] reported detection of zeranol and TBA residues in $100 \%$ and $80 \%$ of samples tested, respectively; reported concentrations were considerably higher, approaching ppm concentrations is some instances. Given the limited clarity provided regarding the methods and meat sourcing, confidence in the findings was low.

\section{FDA Hormone Residue Tolerance Levels}

The FDA is responsible for setting levels of tolerance for residues of hormones that may remain in animal products as a result of their administration to food animals. These levels are set as residue limits in the specific tissues of a particular species (Table 2). No residue tolerance regulations are in place for TBA or zeranol; the rationale for their absence is likely the
FDA's position that residues of human health concern are unlikely under permitted drug use specifications. Interestingly, in the aforementioned example (NADA 141-043, for a combination implant drug containing TBA and estradiol benzoate), the agency notes that a marker residue is not needed because the tested edible tissues of steers are below codified "safe concentrations." Despite this logic, however, an examination of 30-day liver concentration of TBA is reported as "mean: 85.23 ppb SD: 45.15 ppb," which is less than a single standard deviation away from the codified safe concentration of $100 \mathrm{ppb}$.

Hormone Residue Testing under the USDA/FSIS/National Residue Program

Within the U.S., the National Residue Program (NRP, which is administered by the Food Safety and Inspection Service of the USDA) is the only federal effort that routinely examines animal products for drug residues. Challenges exist in the utilization of NRP data for the purpose of understanding dietary hormone exposure. In its entire history, the NRP has only examined TBA, MGA, and zeranol. There are year-to-year variations in which of these hormones is subjected to examination, and in some years, none are assessed (Fig. 1). Testing is performed in tissues not commonly consumed by people (e.g., kidney and liver), requiring extrapolations to estimate concentrations in muscle tissue and milk. Further, residue data reporting is extremely crude, and does not allow for the construction of residue concentration distributions or descriptive statistics. Many of these shortcomings are likely a result of the core conflict between the purpose of the NRP and the need for exposure assessment, as the primary purpose of the NRP - the removal of animal products with violative residue levels from the food supply - may require data that is different from that needed to understand residue exposure in people.

Table 2 FDA hormone tolerance limits

\begin{tabular}{|c|c|c|c|c|c|}
\hline Hormone & $\begin{array}{l}\text { Muscle } \\
\mathrm{mg} / \mathrm{kg}\end{array}$ & Liver & Kidney & Fat & $\begin{array}{l}\text { ADI } \\
m g / k g B W-d a y\end{array}$ \\
\hline Estradiol $^{\mathrm{a}}$ & 0.00012 & 0.00048 & 0.00036 & 0.00024 & $\mathrm{~N} / \mathrm{A}$ \\
\hline Melengestrol acetate & N/A & N/A & N/A & 0.0025 & N/A \\
\hline Progesterone & 0.005 & 0.015 & 0.03 & 0.03 & N/A \\
\hline Testosterone propionate $^{\mathrm{a}}$ & 0.00064 & 0.0026 & 0.0019 & 0.0013 & $\mathrm{~N} / \mathrm{A}$ \\
\hline Trenbolone & \multicolumn{4}{|c|}{ Tolerance not needed ${ }^{\mathrm{b}}$} & 0.004 \\
\hline Zeranol & \multicolumn{4}{|c|}{ Tolerance not needed ${ }^{\mathrm{b}}$} & 0.00125 \\
\hline
\end{tabular}

${ }^{a}$ Residues of these compounds are not permitted in excess of these increments above the concentrations of these compounds naturally present in untreated animals

${ }^{\mathrm{b}}$ As specified in the CFR

$A D I$ acceptable daily intake, $N / A$ not applicable

Code of Federal Regulations Title 21 Subchapter E - Animal Drugs, Feeds, and Related Products, Part 556: Tolerances for Residues of New Animal Drugs in Food 
Fig. 1 Hormone monitoring in the USDA/FSIS National Residue Program, by year. *Data represent the number of samples examined under the monitoring program, which is the routine surveillance program. A small number of additional samples are analyzed in selected years under inspectorgenerated mechanisms or in imported animal products

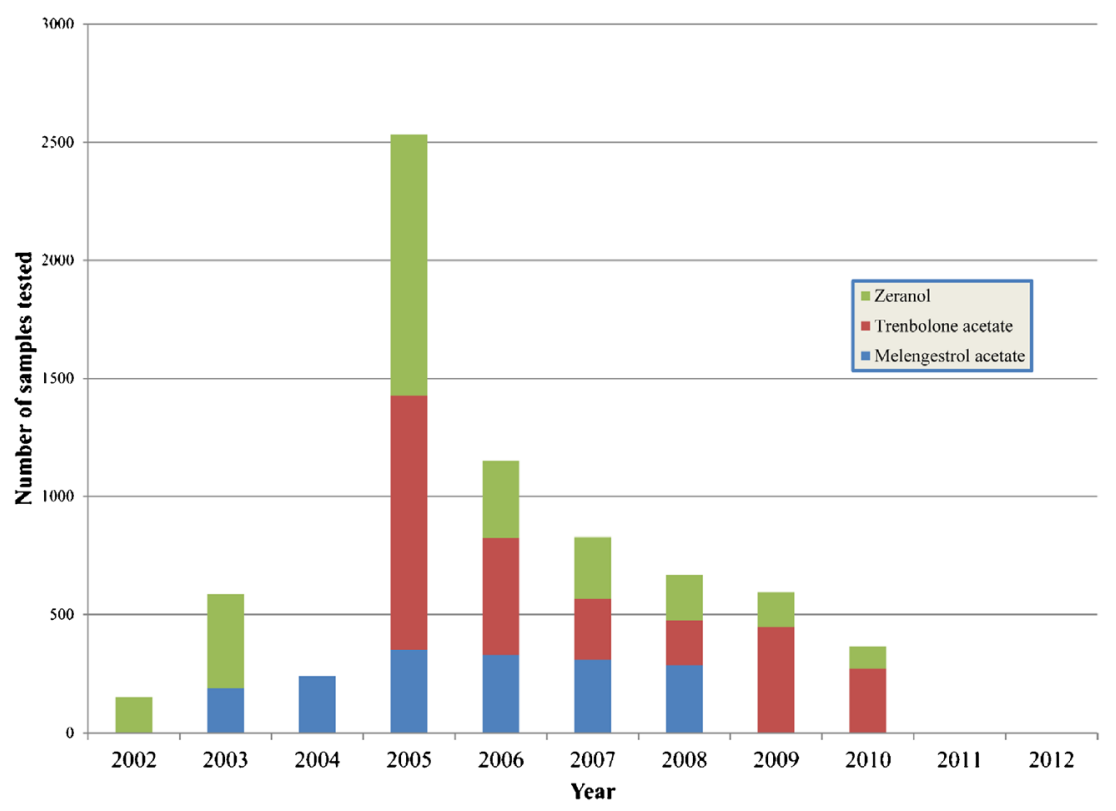

\section{Characterizing Intake of Animal Products}

Estimation of the intake of hormones through consumption of animal products requires an understanding of patterns of consumption for meat, milk, and egg products. Nationwide dietary intake data (including entries for animal products) are collected in the What We Eat in America (WWEIA) dietary survey of the National Health and Nutrition Examination Survey (NHANES) $[100,101]$. These data were analyzed by the EPA and reported by product as per capita or consumer-only intake rates in the 2011 Exposure Factors Handbook (EFH) [102]. In some cases, animal product intake rates are reported by life stage (or age grouping) or by race/ethnicity. Table 3 summarizes intake rates from the EFH for animal products.

Per capita intake rates for dairy products were the highest of all animal products among the general population, more than eight times that of beef or poultry, and nearly 17 times that of pork products. Based on survey data, the EPA reported that $88 \%, 80 \%$, and $75 \%$ of persons consume beef, pork, and
Table 3 Per capita body weightadjusted intake rates for animal products

\begin{tabular}{llllllc}
\hline & $\begin{array}{l}\text { Total meat } \\
\text { g/kg-day }\end{array}$ & Beef & Pork & Poultry & Dairy products & Eggs \\
\hline Whole population & 2.00 & 0.77 & 0.39 & 0.77 & 6.60 & 0.4 \\
Age group & & & & & & \\
$\quad$ Birth to 1 year & 2.70 & 0.34 & 0.17 & 0.69 & 11.70 & 0.3 \\
1 to 2 years & 4.10 & 1.38 & 0.75 & 1.87 & 43.20 & 1.3 \\
3 to 5 years & 3.90 & 1.42 & 0.79 & 1.65 & 24.00 & 0.91 \\
6 to 12 years & 2.80 & 1.11 & 0.52 & 1.18 & 12.90 & 0.51 \\
13 to 19 years & 2.00 & 0.83 & 0.36 & 0.80 & 5.50 & 0.33 \\
20 to 49 years & 1.80 & 0.73 & 0.36 & 0.71 & 3.50 & 0.31 \\
Females 13 to 49 years & 1.60 & 0.60 & 0.28 & 0.66 & 3.80 & 0.33 \\
50 years and older & 1.40 & 0.58 & 0.33 & 0.50 & 3.30 & ND \\
Race/ethnicity & & & & & & 0.48 \\
Mexican American & 2.30 & 0.94 & 0.43 & 0.82 & 8.60 & 0.36 \\
Non-Hispanic black & 2.20 & 0.79 & 0.40 & 1.01 & 5.00 & ND \\
Non-Hispanic white & 1.90 & 0.74 & 0.38 & 0.70 & 6.60 & ND \\
Other Hispanic & 2.30 & 0.89 & 0.36 & 0.97 & 8.10 & 6.70 \\
Other race - including multiple & 2.30 & 0.84 & 0.41 & 1.00 & & \\
\hline
\end{tabular}


poultry, respectively (an estimate of the percentage of persons consuming dairy products was not available). Consumption of meat and dairy products, on a body-weight-adjusted basis, is highest early in life.

The EFH includes some animal product intake data specific to premenopausal women. Women between the ages of 13 and 49 years consume approximately $20 \%$ less meat and half the amount of dairy products compared to the general population, after adjusting for body weight. While data specific to women 50 years of age and older were not available, estimates for persons 50+ (for males and females combined) suggest that both total meat intake and beef, poultry, and dairy product intake were further reduced from women aged 13-49; pork intake was slightly higher. Data for animal product-specific intake rates for postmenopausal women are needed in order to estimate dietary hormone exposure levels in this subpopulation.

\section{Discussion and Conclusions}

We have assembled literature relevant to the hazard identification, dose-response assessment, and exposure assessment steps of the NRC risk paradigm. Our review of the published literature has identified gaps in current knowledge germane to each step. A description of the most important of these gaps follows.

There appears to be a lack of chronic (especially lifetime) bioassays of oral toxicity of the seven hormone compounds in the published literature. While evaluations of these compounds are submitted to the FDA as part of the drug approval process,

\section{Table 4}

GAP 1: Important gaps remain in the published literature concerning the dose-response relationships between oral exposures to hormones and various health outcomes. Currently, there are few high-quality chronic/lifetime, oral studies; without these, uncertainty clouds the understanding of the biological significance (if any) of long-term, low-dose hormone exposures through diet. Furthermore, available mechanistic and epidemiologic studies suggest that traditional toxicologic endpoints may not be appropriate for evaluation of hormone-mediated carcinogenicity.

OPPORTUNITY 1: Independent toxicologic studies that examine chronic or lifetime oral exposure to low doses of FDA-approved hormonal animal drugs and/or their active metabolites in relation to both frank effects (e.g., breast carcinomas) and upstream precursors (e.g., perturbations in endogenous hormone levels) would allow for determination of exposures that pose an acceptable (or no) risk, and thus support evidence-based regulatory decision-making by the FDA.

GAP 2: Better information is needed regarding the toxicological consequences of hormone exposure during specific life stages or critical "windows of toxicity." In the case of breast cancer, it is possible that perturbations of circulating hormone levels at certain life stages may have greater biological significance than perturbations at other times. Identification of these windows is important. and would be complemented by an understanding of dietary patterns during these key time periods.

OPPORTUNITY 2: In addition to chronic or lifetime studies, developmental toxicity studies that incorporate in utero or pre-pubertal exposures, and build upon existing developmental studies of the compounds covered by this report, may reveal specific effects not detected in studies that are not reflective of the growing knowledge of the importance of these windows of toxicity.

GAP 3: Too little information is available regarding the human food safety evaluations that form the scientific basis for FDA animal drug approvals, especially for hormones. Specifically, toxicological and residue assessment of hormones is supported primarily by industry studies that are not made available to independent scientists for review; as a result, it is impossible to assess potential impacts of study age and conflict of interest on the quality of the studies and how they are interpreted.

OPPORTUNITY 3: Independent review of industry submissions could be possible if study reports and the associated data submitted to the FDA in the drug approval process were made available to independent researchers. Legal measures should be pursued to gain access to these documents. FOIA requests may be an opportunity to secure access to these studies.

GAP 4: Dietary intake rate data are limited and provide little information about the distributions of consumption rates (across life stage, gender, race/ethnicity, etc.) for specific animal products. This is especially important for development of hormone-specific intake rates. With regard to breast cancer, intake rates for specific animal products are not available for post-menopausal women, limiting the ability to understand how diet may contribute to hormone exposure at important life stages.

OPPORTUNITY 4: Raw data from WWEIA (which are publicly accessible), especially across multiple examination cycles/years, allow for in-depth analyses that could yield more precise estimations of intake rate distributions for subgroups of particular concern in breast cancer prevention efforts. These rates would better support dietary exposure estimation for hormones in vulnerable populations.

GAP 5: Federal approaches to hormone residue testing are inadequate. A small, changing number of compounds are not consistently tested from year to year. The tests rely on potentially outdated methods and do not permit longitudinal evaluation of residue levels in animal products. A search of the open literature did not identify representative studies of residues in retail animal products.

OPPORTUNITY 5: A review of novel analytical methods for hormone residue analysis would yield recommendations for modernizing regulatory methods for federal residue monitoring systems, and may facilitate a uniform approach for testing retail animal products. Given the limitations of the NRP, independently conducted market-basket studies of retail meats that incorporate highly sensitive analytic methods would yield data to support defensible estimations of dietary hormone exposures at biologically-relevant concentrations.

*Our review has revealed that numerous deficiencies exist in publicly available literature. Here, we identify key gaps in current knowledge and suggest opportunities for further research that would likely generate the foundation for interventions, if needed 
this information is not made available to the public for independent evaluation, and thus these evaluations cannot be used to estimate risks and related burdens for persons consuming animal products. The existing literature primarily utilizes subcutaneous dose delivery in which the bioavailability of the administered dose approaches $100 \%$. This route does not account for variation in toxicological parameters that may result from differences in bioavailability or metabolism of compounds that can occur following oral exposure. Furthermore, the endpoints assessed in the published literature may not reflect an emerging understanding of the importance of upstream markers (e.g., circulating hormone levels) on subsequent clinical disease. Published animal studies have studied adverse effects resulting from exposure during key periods of pregnancy or pre-puberty, suggesting that the timing of exposure, in addition to the level of exposure, plays a key role in the biological significance of exposure to exogenous hormones.

Products containing the hormones reviewed in this paper were originally approved by the FDA several decades ago, using studies submitted by the industry; the most recent approval, for rBGH, came in 1993. The agency based subsequent approvals of products that contained these compounds on the studies submitted in support of original approvals. The FDA also does not routinely review and update approvals. As a consequence, the approvals of many hormone products are based on studies conducted decades ago by companies seeking approval, and predate current scientific understanding of relevant human health risks, such as endocrine disruption [103]. The studies are not easily obtained by scientists outside the FDA - typically, only summaries of the studies are posted online, and access to older summaries not available online or studies that are referenced requires FOIA submission. In our experience, including requests for hormone studies, the time from submission to receipt of records has spanned several years.

The ability to estimate dietary hormone exposure is severely hampered by the state of the existing literature. Residue depletion studies, which are submitted to the FDA as part of drug approvals, are difficult to access, and when access is possible, careful examination of study summaries suggests that conclusions drawn from these studies are not well founded. Literature describing the residue content of retail animal products is limited; the best available studies primarily focus on estrogens in dairy products. Studies of retail animal tissue products are rare. Regulatory methods specified for analysis of TBA, MGA, and zeranol frequently rely on older GC-MS-based methods, and may not be on par with a wide array of newer available methods, which are supported by a rich literature.

Body-weight-adjusted per capita animal product intake estimates are available from the EPA EFH. These are the bestsuited estimates for assessing levels of hormone exposure through food products, as they are derived from the most recent synthesis of NHANES dietary data. The EPA estimates suggest that dairy products are consumed at considerably higher rates than other animal products, and that bodyweight-adjusted animal product intake peaks early in life (between 1 and 5 years), and declines steadily over the remaining life stages. Animal product consumption rates specific to postmenopausal women are not available in the EFH, though combined rates for all persons over 50 are available. Data show that women of premenopausal age consumed approximately $20 \%$ less meat per body weight than the general population, and between $14 \%$ and $28 \%$ less of specific meat types. Animal product consumption rates were highest among nonwhites, with consumption rates varying by product-race/ethnicity combination.

In this review, we have identified key limitations that preclude conduct of quantitative dose-response and exposure assessments. As a result, at present, it is not possible to provide a quantitative characterization of risks that result from the use of hormonal drugs in food animal production. As such, understanding the role of dietary hormone exposure in the population burden of breast cancer is not possible at this time. In Table 4, we highlight critical gaps in our understanding of the population burden imposed by hormone use as well as potential opportunities for advancing the science.

Acknowledgments This work was funded in part by the California Breast Cancer Research Program. The Johns Hopkins Center for a Livable Future is supported by a grant from the GRACE Communications Foundation (but did not provide funding specific to this project). The funders had no role in study design, data collection and analysis, decision to publish, or preparation of the manuscript.

\section{Compliance with Ethics Guidelines}

Conflict of Interest Keeve E. Nachman and Tyler J. S. Smith each declare that they have no conflict of interest.

Human and Animal Rights and Informed Consent This article does not contain any studies with human or animal subjects performed by any of the authors.

\section{References}

Papers of particular interest, published recently, have been highlighted as:

- Of importance

1. Surveillance Epidemiology and End Results [SEER]. SEER Stat Fact Sheets. Breast 2013. Available at: http://seer.cancer.gov/ statfacts/html/breast.html. Accessed 29 Sept 2013.

2. Yager JD, Davidson NE. Estrogen carcinogenesis in breast cancer. N Engl J Med. 2006;354:270-82. This paper reviews the epidemiologic and mechanistic evidence on the relationship between estrogen and breast cancer. It includes several large, prospective 
studies on hormone-replacement therapy, including estrogen and human breast cancer risk.

3. Vandenberg LN, Colborn T, Hayes TB, Heindel JJ, Jacobs Jr DR, Lee DH, et al. Hormones and endocrine-disrupting chemicals: low-dose effects and nonmonotonic dose responses. Endocr Rev. 2012;33:378-455.

4. World Health Organization/United Nations Environment Programme. State of the Science of Endocrine Disrupting Chemicals 2012. Available at: http://www.who.int/ceh/ publications/endocrine/en/index.html. Accessed 29 Sept 2013.

5. United States Food and Drug Administration. Animal Drugs @ FDA 2013 Available at: http://www.accessdata.fda.gov/scripts/ animaldrugsatfda. Accessed 25 Sept 2013.

6. Galbraith H. Hormones in international meat production: biological, sociological and consumer issues. Nutr Res Rev. 2002;15: 293-314.

7. American Cancer Society. Recombinant Bovine Growth Hormone 2013. Available at: http://www.cancer.org/cancer/ cancercauses/othercarcinogens/athome/recombinant-bovinegrowth-hormone. Accessed 29 Sept 2013.

8. Johnson R. The U.S.-EU beef hormone dispute. Washington: Congressional Research Service; 2012.

9. National Research Council. Risk assessment in the federal government: managing the process. Washington: National Academy Press; 1983.

10. National Research Council Committee on Improving Risk Analysis Approaches Used by the US EPA: Science and decisions: advancing risk assessment. National Academies Press; 2009.

11. United States Food and Drug Administration. From an idea to the marketplace. J Anim Drug Appr Process. 2013. Available at: http://www.fda.gov/AnimalVeterinary/ResourcesforYou/ AnimalHealthLiteracy/ucm219207.htm

12. European Commission. Opinion of the scientific committee on veterinary measures relating to Public Health 1999. Available at: http://ec.europa.eu/food/fs/sc/scv/out21 en.pdf. Accessed 29 Sept 2013.

13. Kaaks R, Rinaldi S, Key TJ, Berrino F, Peeters PHM, Biessy C, et al. Postmenopausal serum androgens, oestrogens and breast cancer risk: the European prospective investigation into cancer and nutrition. Endocr-Relat Cancer. 2005;12:1071-82.

14. Key T, Appleby P, Barnes I, Reeves G, Endogenous H. Breast Cancer Collaborative G: Endogenous sex hormones and breast cancer in postmenopausal women: reanalysis of nine prospective studies. J Natl Cancer Inst. 2002;94:606-16.

15. Missmer SA, Eliassen AH, Barbieri RL, Hankinson SE. Endogenous estrogen, androgen, and progesterone concentrations and breast cancer risk among postmenopausal women. J Natl Cancer Inst. 2004;96:1856-65.

16. Adams JB. Adrenal androgens and human breast cancer: a new appraisal. Breast Cancer Res Treat. 1998;51:183-8.

17. Dimitrakakis C, Zhou J, Bondy CA. Androgens and mammary growth and neoplasia. Fertil Steril. 2002;77 Suppl 4:S26-33.

18. Liao DJ, Dickson RB. Roles of androgens in the development, growth, and carcinogenesis of the mammary gland. J Steroid Biochem Mol Biol. 2002;80:175-89.

19. Slob AK, den Hamer R, Woutersen PJ, van der Werff ten Bosch JJ. Prenatal testosterone propionate and postnatal ovarian activity in the rat. Acta Endocrinol (Copenh). 1983;103:420-7.

20. Huffman L, Hendricks SE. Prenatally injected testosterone propionate and sexual behavior of female rats. Physiol Behav. 1981;26: 773-8.

21. Hotchkiss AK, Lambright CS, Ostby JS, Parks-Saldutti L, Vandenbergh JG, Gray Jr LE. Prenatal testosterone exposure permanently masculinizes anogenital distance, nipple development, and reproductive tract morphology in female Sprague-Dawley rats. Toxicol Sci Off J Soc Toxicol. 2007;96:335-45.

22. Wolf CJ, Hotchkiss A, Ostby JS, LeBlanc GA, Gray Jr LE. Effects of prenatal testosterone propionate on the sexual development of male and female rats: a dose-response study. Toxicol Sci Off J Soc Toxicol. 2002;65:71-86.

23. Pottier J, Cousty C, Heitzman RJ, Reynolds IP. Differences in the Biotransformation of a 17-Beta-Hydroxylated Steroid, Trenbolone Acetate, in Rat and Cow. Xenobiotica. 1981;11:489-500.

24. Richold M. The genotoxicity of trenbolone, a synthetic steroid. Arch Toxicol. 1988;61:249-58.

25. Schiffmann D, Hieber L, Schmuck G, Pechan R, Metzler M, Henschler D. Trenbolone induces micronucleus formation and neoplastic transformation in Syrian hamster embryo fibroblasts but not in mouse C3H10T1/2 cells. Arch Toxicol. 1988;62:49-53.

26. Lutz WK, Deuber R, Caviezel M, Sagelsdorff P, Friederich U, Schlatter C. Trenbolone growth promotant: covalent DNA binding in rat liver and in Salmonella typhimurium, and mutagenicity in the Ames test. Arch Toxicol. 1988;62:103-9.

27. Lasne C, Lu YP, Orfila L, Ventura L, Chouroulinkov I. Study of various transforming effects of the anabolic agents trenbolone and testosterone on Syrian hamster embryo cells. Carcinogenesis. 1990;11:541-7.

28. Tsutsui T, Komine A, Huff J, Barrett JC. Effects of testosterone, testosterone propionate, 17 beta-trenbolone and progesterone on cell transformation and mutagenesis in Syrian hamster embryo cells. Carcinogenesis. 1995;16:1329-33.

29. Wilson VS, Lambright C, Ostby J, Gray Jr LE. In vitro and in vivo effects of 17beta-trenbolone: a feedlot effluent contaminant. Toxicol Sci Off J Soc Toxicol. 2002;70:202-11.

30. Hotchkiss AK, Furr J, Makynen EA, Ankley GT, Gray LE. In utero exposure to the environmental androgen trenbolone masculinizes female Sprague-Dawley rats. Toxicol Lett. 2007;174:3141.

31. Hotchkiss AK, Nelson RJ. An environmental androgen, 17 betatrenbolone, affects delayed-type hypersensitivity and reproductive tissues in male mice. J Toxicol Environ Health A. 2007;70:138 40 .

32. Olsen NJ, Kovacs WJ. Gonadal steroids and immunity. Endocr Rev. 1996;17:369-84.

33. Klein SL. The effects of hormones on sex differences in infection: from genes to behavior. Neurosci Biobehav Rev. 2000;24:627-38.

34. United States Food and Drug Administration. NADA 138-612 Finaplix(R) - Original Approval 1986 Available at: http://www.fda. gov/AnimalVeterinary/Products/ApprovedAnimalDrugProducts/ FOIADrugSummaries/ucm111214.htm. Accessed 28 Sept 2013.

35. United States Food and Drug Administration. NADA 141043 Synovex Plus(R) - Original Approval 1996 Available at: http://www.fda.gov/AnimalVeterinary/Products/ ApprovedAnimalDrugProducts/FOIADrugSummaries/ ucm116149.htm.

36. 20 CFR § 556.739. In Book 20 CFR § 556.739 (ed.). City; 2012.

37. Joint FAO/WHO Expert Committee on Food Additives [JECFA]. Evaluation of Certain Veterinary Drug Residues in Food 1988 Available at: http://whqlibdoc.who.int/trs/WHO_TRS_763.pdf. Accessed 29 Sept 2013.

38. Kuiper GGJM, Carlsson B, Grandien K, Enmark E, Häggblad J, Nilsson S, et al. Comparison of the Ligand Binding Specificity and Transcript Tissue Distribution of Estrogen Receptors $\alpha$ and $\beta$. Endocrinology. 1997;138:863-70.

39. Leffers H, Naesby M, Vendelbo B, Skakkebaek NE, Jorgensen M. Oestrogenic potencies of Zeranol, oestradiol, diethylstilboestrol, Bisphenol-A and genistein: implications for exposure assessment of potential endocrine disrupters. Hum Reprod. 2001;16:1037-45. 
40. Liu S, Lin YC. Transformation of MCF-10A human breast epithelial cells by zeranol and estradiol-17beta. Breast J. 2004;10: 514-21.

41. Yuri T, Tsukamoto R, Miki K, Uehara N, Matsuoka Y, Tsubura A. Biphasic effects of zeranol on the growth of estrogen receptorpositive human breast carcinoma cells. Oncol Rep. 2006;16: 1307-12.

42. Ye WP, Xu PP, Jen R, Feng ER, Zhong SY, Li H, et al. Zeranol down-regulates p53 expression in primary cultured human breast cancer epithelial cells through epigenetic modification. Int J Mol Sci. 2011;12:1519-32.

43. Zhong S, Ye W, Lin S-H, Liu J-Y, Leong J, Mai C, et al. Zeranol induces cell proliferation and protein disulfide isomerase expression in mammary gland of ACI Rat. Anticancer Res. 2011;31: 1659-65.

44. Ye WP, Xu PP, Threlfall WR, Jen R, Li H, Lin SH, et al. Zeranol Enhances the Proliferation of Pre-adipocytes in Beef Heifers. Anticancer Res. 2009;29:5045-52.

45. Sheffield L, Welsch C. Zeranol ( $\beta$-resorcylic acid lactone), a common residous component of natural foodstuffs, stimulates developmental growth of the mouse mammary gland. Cancer Lett. 1985;28:77-83

46. Nikaido Y, Danbara N, Tsujita-Kyutoku M, Yuri T, Uehara N, Tsubura A. Effects of prepubertal exposure to xenoestrogen on development of estrogen target organs in female CD-1 mice. In Vivo. 2005;19:487-94.

47. Yuri T, Nikaido Y, Shimano N, Uehara N, Shikata N, Tsubura A. Effects of prepubertal zeranol exposure on estrogen target organs and N-methyl-N-nitrosourea-induced mammary tumorigenesis in female Sprague-Dawley rats. In Vivo. 2004;18:755-61.

48. Coe JE, Ishak KG, Ward JM, Ross MJ. Tamoxifen prevents induction of hepatic neoplasia by zeranol, an estrogenic food contaminant. Proc Natl Acad Sci U S A. 1992;89:1085-9.

49. Gulbahar MY, Yuksel H, Guvenc T, Okut H. Assessment of proliferative activity by AgNOR and PCNA in prostatic tissues of ram lambs implanted with zeranol. Reprod Domest Anim Zuchthygiene. 2005;40:468-74.

50. Conner P. Breast response to menopausal hormone therapyaspects on proliferation, apoptosis and mammographic density. Ann Med. 2007;39:28-41.

51. Murdoch WJ, Van Kirk EA, Isaak DD, Shen Y. Progesterone facilitates cisplatin toxicity in epithelial ovarian cancer cells and xenografts. Gynecol Oncol. 2008;110:251-5.

52. Fonseca EB, Celik E, Parra M, Singh M, Nicolaides KH. Progesterone and the risk of preterm birth among women with a short cervix. N Engl J Med. 2007;357:462-9.

53. Nilsen J, Brinton RD. Impact of progestins on estrogen-induced neuroprotection: synergy by progesterone and 19-norprogesterone and antagonism by medroxyprogesterone acetate. Endocrinology. 2002;143:205-12.

54. Beral V, Bull D, Doll R, Key T, Peto R, Reeves G. Breast cancer and hormone replacement therapy: collaborative reanalysis of data from 51 epidemiological studies of 52, 705 women with breast cancer and 108, 411 women without breast cancer. Lancet. 1997;350:1047-59.

55. Million Women Study Collaborators. Breast cancer and hormonereplacement therapy in the Million Women Study. Lancet. 2003;362:419-27.

56. Conneely OM, Jericevic BM, Lydon JP. Progesterone receptors in mammary gland development and tumorigenesis. J Mammary Gland Biol Neoplasia. 2003;8:205-14.

57. Hankinson SE, Eliassen AH. Endogenous estrogen, testosterone and progesterone levels in relation to breast cancer risk. J Steroid Biochem Mol Biol. 2007;106:24-30.

58. Raafat AM, Hofseth LJ, Haslam SZ. Proliferative effects of combination estrogen and progesterone replacement therapy on the normal postmenopausal mammary gland in a murine model. Am J Obstet Gynecol. 2001;184:340-9.

59. Shimada H, Hochadel JF, Waalkes MP. Progesterone pretreatment enhances cellular sensitivity to cadmium despite a marked activation of the metallothionein gene. Toxicol Appl Pharmacol. 1997; 142:178-85.

60. Shiraishi N, Barter RA, Uno H, Waalkes MP. Effect of progesterone pretreatment on cadmium toxicity in the male fischer (F344/NCR) Rat. Toxicol Appl Pharmacol. 1993;118:113-18.

61. Metherall JE, Waugh K, Li H. Progesterone inhibits cholesterol biosynthesis in cultured cells: accumulation of cholesterol precursors. J Biol Chem. 1996;271:2627-33.

62. Krzeminski LF, Cox BL, Gosline RE. Fate of radioactive melengestrol acetate in the bovine. J Agric Food Chem. 1981;29:387-91.

63. Sud SC, Meites J. Effect of melengestrol acetate on the organ weight \& the mammary lobulo-alveolar development in rats. Indian J Exp Biol. 1971;9:138-41.

64. Nagasawa H, Sakagami N, Ohbayashi R, Yamamoto K, Petrow V. Effect of megestrol acetate or melengestrol acetate on preneoplastic and neoplastic mammary growth in mice. Anticancer Res. 1988;8:1399-403.

65. Deerberg F, Pohlmeyer G, Lorcher K, Petrow V. Total suppression of spontaneous endometrial carcinoma in BDII/Han rats by melengestrol acetate. Oncology. 1995;52:319-25.

66. Harrenstien LA, Munson L, Seal US, Riggs G, Cranfield MR, Klein L, et al. Mammary cancer in captive wild felids and risk factors for its development: a retrospective study of the clinical behavior of 31 cases. J Zoo Wildlife Med. 1996;27:468-76.

67. Kazensky CA, Munson L, Seal US. The effects of melengestrol acetate on the ovaries of captive wild felids. J Zoo Wildlife Med. 1998;29:1-5

68. Imwalle DB, Patterson DJ, Schillo KK. Effects of melengestrol acetate on onset of puberty, follicular growth, and patterns of luteinizing hormone secretion in beef heifers. Biol Reprod. 1998;58: 1432-6.

69. Lange IG, Daxenberger A, Meyer HH, Rajpert-De Meyts E, Skakkebaek NE, Veeramachaneni DN. Quantitative assessment of foetal exposure to trenbolone acetate, zeranol and melengestrol acetate, following maternal dosing in rabbits. Xenobiotica. 2002;32:641-51.

70. Leroith D, Werner H, Beitner-Johnson D, Roberts AT. Molecular and cellular aspects of the insulin-like growth factor i receptor. Endocr Rev. 1995; 16:143-63.

71. Juskevich JC, Guyer CG. Bovine growth-hormone - human food safety evaluation. Science. 1990;249:875-84.

72. United States Food and Drug Administration. Freedom of Information Summary: Posilac (Sterile Sometribove Zinc Suspension) 1993 Available at: http://www.fda.gov/downloads/ AnimalVeterinary/Products/ApprovedAnimalDrugProducts/ FOIADrugSummaries/ucm050022.pdf. Accessed 30 Sept 2013.

73. Raymond R, Bales CW, Bauman DE, Clemmons D, Kleinman R, Lanna D, Nickerson S, Sejrsen K. Recombinant Bovine Somatotropin (rbST): A Safety Assessment. In ADSA-CSASASAS Joint Annual Meeting; Montreal, Canada. 2009.

74. Renehan AG, Zwahlen M, Minder C, O'Dwyer ST, Shalet SM, Egger M. Insulin-like growth factor (IGF)-I, IGF binding protein3 , and cancer risk: systematic review and meta-regression analysis. Lancet. 2004;363:1346-53. These studies report meta-analyses regarding relationships between circulating IGF-1 and cancer risk. They consider large studies that raise concerns about the use of rBGH in milk production and potential increases to IGF-I in consumers of dairy products from treated animals.

75. Endogenous Hormones and Breast Cancer Collaborative Group. Insulin-like growth factor 1 (IGF1), IGF binding protein 3 (IGFBP3), and breast cancer risk: pooled individual data analysis 
of 17 prospective studies. Lancet Oncol. 2010;11:530-42. These studies report meta-analyses regarding relationships between circulating IGF-1 and cancer risk. They consider large studies that raise concerns about the use of $r B G H$ in milk production and potential increases to IGF-1 in consumers of dairy products from treated animals.

76. Pollak M. Insulin and insulin-like growth factor signalling in neoplasia. Nat Rev Cancer. 2008;8:915-28.

77. Holmes MD, Pollak MN, Willett WC, Hankinson SE. Dietary correlates of plasma insulin-like growth factor I and insulin-like growth factor binding protein 3 concentrations. Cancer Epidemiol Biomark Prevent Publ Am Assoc Cancer Res Cosponsored Am Soci Prevent Oncol. 2002;11:852-61.

78. Norat T, Dossus L, Rinaldi S, Overvad K, Gronbaek H, Tjonneland A, et al. Diet, serum insulin-like growth factor-I and IGF-binding protein-3 in European women. Eur J Clin Nutr. 2007;61:91-8.

79. Boyd NF, Martin LJ, Noffel M, Lockwood GA, Trichler DL. A meta-analysis of studies of dietary fat and breast cancer risk. Br J Cancer. 1993;68:627-36.

80. Missmer SA, Smith-Warner SA, Spiegelman D, Yaun SS, Adami HO, Beeson WL, et al. Meat and dairy food consumption and breast cancer: a pooled analysis of cohort studies. Int $\mathrm{J}$ Epidemiol. 2002;31:78-85.

81. Danby FW. Comparing rbST-Free, organic, and conventional milk. J Am Diet Assoc. 2008;108:1991.

82. Vicini J, Etherton T, Kris-Etherton P, Ballam J, Denham S, Staub $\mathrm{R}$, et al. Survey of retail milk composition as affected by label claims regarding farm-management practices. J Am Diet Assoc. 2008;108:1198-203.

83. United States Food and Drug Administration. NADA 141-043 Synovex ${ }^{\circledR}$ Plus - original approval 1996 Available at: NADA 141043 Synovex ${ }^{\circledR}$ Plus - original approval. Accessed 23 Sept 2013.

84. Daxenberger A, Meyer K, Hageleit M, Meyer H. Detection of melengestrol acetate residues in plasma and edible tissues of heifers. Vet Q. 1999;21:154-8.

85. European Food Safety Authority. Opinion of the scientific panel oon contaminants in the food chain on a request from the European Commission related to hormone residues in bovine meat and meat products, Question $\mathrm{N}^{\circ}$ EFSA-Q-2005-048. EFSA J. 2007;510:1-62.

86. Farlow DW, Xu X, Veenstra TD. Quantitative measurement of endogenous estrogen metabolites, risk-factors for development of breast cancer, in commercial milk products by LC-MS/MS. J Chromatogr B. 2009;877:1327-34.

87. Macrina AL, Ott TL, Roberts RF, Kensinger RS. Estrone and estrone sulfate concentrations in milk and milk fractions. J Acad Nutr Dietet. 2012;112:1088-93.

88. Courant F, Antignac J-P, Laille J, Monteau F, Andre F, Le Bizec B. Exposure assessment of prepubertal children to steroid endocrine disruptors. 2. Determination of steroid hormones in milk, egg, and meat samples. J Agric Food Chem. 2008;56:3176-84.
89. Courant F, Antignac J-P, Maume D, Monteau F, Andre F, Le Bizec B. Determination of naturally occurring oestrogens and androgens in retail samples of milk and eggs. Food Addit Contam. 2007;24: $1358-66$.

90. Farlow D, Xu X, Veenstra T. Comparison of estrone and $17 \beta$ estradiol levels in commercial goat and cow milk. J Dairy Sci. 2012;95:1699-708.

91. Malekinejad H, Scherpenisse P, Bergwerff AA. Naturally occurring estrogens in processed milk and in raw milk (from gestated cows). J Agric Food Chem. 2006;54:9785-91.

92. Pape-Zambito D, Roberts R, Kensinger R. Estrone and $17 \beta$ estradiol concentrations in pasteurized-homogenized milk and commercial dairy products. J Dairy Sci. 2010;93:2533-40.

93. Daxenberger A, Sauerwein H, Breier BH. Increased milk levels of insulin-like growth factor 1 (IGF-1) for the identification of bovine somatotropin (bST) treated cows $\dagger$. Analyst. 1998;123: 2429-35.

94. European Commission. Report on Public Health Aspects of the Use of Bovine Somatotrophin - 15-16 March 1999. 1999 Available at: http://ec.europa.eu/food/fs/sc/scv/out19_en.html. Accessed 24 Sept 2013.

95. Joint FAO/WHO Expert Committee on Food Additives. Evaluation of Certain Veterinary Drug Residues in Food 1999. Available at: http://whqlibdoc.who.int/trs/WHO_TRS_888.pdf. Accessed 25 Sept 2013.

96. Hsieh M-K, Chen H, Chang J-L, She W-S, Chou C-C. Electrochemical detection of zeranol and zearalenone metabolic analogs in meats and grains by screen-plated carbon-plated disposable electrodes. Food Nutr. 2013;4:31-8.

97. Kleinova M, Zöllner P, Kahlbacher H, Hochsteiner W, Lindner W. Metabolic profiles of the mycotoxin zearalenone and of the growth promoter zeranol in urine, liver, and muscle of heifers. J Agric Food Chem. 2002;50:4769-76.

98. Smith G, Heaton K, Sofos J, Tatum J, Aaronson M, Clayton R. Residues of antibiotics, hormones and pesticides in conventional, natural and organic beef. J Muscle Foods. 1997;8:157-72.

99. Nazli B, Colak H, Aydin A, Hampikyan H. The presence of some anabolic residues in meat and meat products sold in Istanbul. Turk J Vet Anim Sci. 2005;29:691-9.

100. United States Department of Agriculture. Food Surveys Products and Services 2013 Available at: http://www.ars.usda.gov/Services/ docs.htm?docid=13793. Accessed 10 Sept 2013.

101. Centers for Disease Control and Prevention. What We Eat in America, DHHS-USDA Dietary Survey Integration. 2010. Available at: http://www.cdc.gov/nchs/nhanes/wweia.htm. Accessed 10 Sept 2013.

102. United States Environmental Protection Agency. Exposure Factors Handbook: 2011 Edition 2011. Available at: http://www.ars.usda. gov/Services/docs.htm?docid=13793. Accessed 10 Sept 2013.

103. Fernández M, Román M, Arrebola J, Olea N. Endocrine disruptors: time to act. Curr Environ Health Res. 2014;1:325-32. 